Article

\title{
Exploring the Effect of College Students' Civic Engagement on Transferable Capabilities during the COVID-19 Pandemic
}

\author{
Dian-Fu Chang ${ }^{1, *(\mathbb{D})}$, Tsun-Ning Chang ${ }^{2}$ and Chia-Chi Chen ${ }^{3} \mathbb{D}$ \\ 1 Department of Education and Futures Design, Tamkang University, New Taipei City 251301, Taiwan \\ 2 Graduate Institute of Educational Policy and Leadership, Tamkang University, New Taipei City 251301, \\ Taiwan; changtsunning@gmail.com \\ 3 Doctoral Program of Educational Leadership and Technology Management, College of Education, \\ Tamkang University, New Taipei City 251301, Taiwan; sophiabv03@gmail.com \\ * Correspondence: 140626@mail.tku.edu.tw
}

Citation: Chang, D.-F.; Chang, T.-N.; Chen, C.-C. Exploring the Effect of College Students' Civic Engagement on Transferable Capabilities during the COVID-19 Pandemic.

Sustainability 2021, 13, 11074.

https://doi.org/10.3390/su131911074

Academic Editors: Osman Titrek and Michele Biasuttie

Received: 10 September 2021

Accepted: 4 October 2021

Published: 7 October 2021

Publisher's Note: MDPI stays neutral with regard to jurisdictional claims in published maps and institutional affiliations.

Copyright: (C) 2021 by the authors Licensee MDPI, Basel, Switzerland. This article is an open access article distributed under the terms and conditions of the Creative Commons Attribution (CC BY) license (https:// creativecommons.org/licenses/by/ $4.0 /)$.

\begin{abstract}
Civic engagement refers to the ways that citizens participate in the life of a community to help shape its future or improve conditions for others. While it might have been shaped by the COVID-19 pandemic recovery, this study explored how college students perceive civic engagement on selected campuses that were partially locked down. We sampled 1036 student volunteers from six universities in Taiwan by using a self-designed module of civic engagement and transferable capabilities. The Student's $t$-test, ANOVA, regression, factor analysis, and structural equation modeling (SEM) were used to interpret the differences and relationships among these variables. This study provides a more detailed example of the current status of civic engagement and its relationship to transferable capabilities in a higher education setting. The related programs and institutions should take responsibility for enhancing students' civic engagement and transferable capabilities during the pandemic. How to ameliorate the situation? The findings suggest that it is necessary to consider a student's academic major, learning experiences in the department, and time spent on related activities during the pandemic recovery. The findings might prove useful to various campuses for enhancing ongoing practices for sustainable development.
\end{abstract}

Keywords: civic engagement; COVID 19; change in higher education; educational systems; effects; SEM; transferable capabilities

\section{Introduction}

During the COVID-19 pandemic, lockdowns severely affected educational institutions and regular campus activities. Various studies focused on the issues related to education, for example, the impact on general education [1,2], international student mobility $[3,4]$, and innovative learning technology issues [5-7]. In this study, we are concerned with civic engagement on campus and if it has been seriously impeded during the pandemic. Since civic engagement has been viewed as one of the crucial activities on campus for sustainable higher education purposes, it is an emerging issue for keeping students active during lockdown. To that end, we designed a framework to determine how influential factors might shape a student's civic engagement.

Civic engagement combines the concepts of community engagement and global citizenship and involves various activities, for example: learning from others, comprehending diversity, developing empathy and social responsibility, working through controversy, developing informed perspectives on social issues, taking an active role in politics, and participating actively in public life and problem-solving [8]. Individuals might be mediators who can transform society, but, during the pandemic, this aspect of civic engagement has been challenged, particularly concerning service-learning programs in higher education, which are meant to benefit students, colleges, and society as a whole. College students are expected to engage in social service to improve their civil responsibility, enhance their 
interpersonal skills, and practice life-long learning. Since the pandemic, various civic engagement and service-learning activities on campus have been blocked, but the effects are still unknown.

Although information on civic engagement in higher education is quite comprehensive, assessment using structural modeling is still limited. Under the circumstances, this study aims to investigate current civic engagement as perceived by students in higher education, specifically by exploring which factors might prompt students to become involved and how civic engagement might influence students' abilities. With these purposes in mind, this study addresses the following research questions:

a. What constitutes students' civic engagement on campus during the COVID-19 pandemic?

b. Do they have any group differences in gender or major?

c. Which factors might impact civic engagement in the current situation?

d. What kind of structural model can interpret the relationship between civic engagement and transferable capabilities?

The rest of this study is presented as follows. First, we review the literature, which includes previous studies on civic engagement and transferable capabilities. Second, the Methods section discusses the research framework, assumptions, instruments, sampling, and statistical analysis. Third, the results-consisting of a factor analysis, comparison of group differences, regression analysis, and structural equation modeling (SEM) - are presented. Fourth, the results of the study are discussed. Finally, conclusions and future suggestions for enhancing student civic engagement are presented.

\section{Literature Review}

\subsection{Concept of Civic Engagement}

Civic engagement has various meanings: community service, regional engagement, public service, public engagement, triple-helix, and social innovation [9]. For example, it is an articulation between three social actors - the university, the private sector, and the government-with the aim of generating regional development in the area of innovation. Higher education can play an important role in this process. Reviewing the related literature, we found there are various perspectives on civic engagement. McIlrath argued that there are abundant studies in the literature, but it is infrequently qualified with definitions [10]; Berger indicated that civic engagement does not specifically refer to political participation, social connectedness, associational membership, volunteerism, community spirit, or co-operative and tolerant moral norms but is rather an umbrella term that encompasses all of these topics while clarifying none [11]. In general, civic engagement acts on a heightened sense of responsibility to one's community, and this may cover a wide range of activities, including developing civic sensitivity, participating in building a civil society, and benefiting the common good. It can also include the ideas related to reciprocity, partnership, inclusion, and social justice [9]. Hence, the Carnegie Foundation's Community Engagement uses campuses to choose a classification of civic engagement as a way to appeal to an institutional identity and a commitment to community engagement $[12,13]$. In higher education, it is understood that civic or community engagement is how a university's knowledge and resources enrich scholarship, research, and creative activity. Moreover, they are expected to prepare educated, engaged citizens to address critical societal issues and contribute to the public good. In this sense, civic engagement can be associated with sustainable development in a society.

Moreover, civic engagement refers to interest and participation in civic, political, or social activities, such as voting, volunteering, or joining a civic group. When youth participate, they empower themselves [14] by acquiring the knowledge, skills, and attitudes to make them successful reformers and formers of networks and coalitions [15-17]. In this sense, civic engagement has been viewed as knowledge combined with the use and acquisition of skills. We assumed that, on campus, it might enhance students' capabilities. 
Higher education has become one of the few public spaces where students can learn to question authority, apply the ideals of engaged citizenship, restate the importance of the public good, and expand their ability to make a difference [8]. Civic engagement has been viewed as values, knowledge, skills, efficacy, and commitment that can be assessed. In 2016, 49 institutions in the United States elected to append civic engagement items to the core survey of the NSSE to assess students' conflict resolution skills and examine how often they engage with local, state, national, and global issues [18]. Related theories and practices developed the notion of civic engagement in different settings. Based on previous discussion, this phenomenon indicated that undergraduate experiences and current curricula should reflect the progress made in incorporating the civic engagement provisions. Creating a meaningful framework for the civic engagement provisions has become one of the crucial components in higher education settings.

\subsection{Transferable Capabilities}

Transferable capabilities refer to skills, knowledge, and abilities that can be transferred. It is often assumed that transferable skills can be reused after the transition to a new situation. For example, transferable skills are skills that are relevant and helpful across different situations and areas of life. Such skills are often seen as a crucial factor adding to the employability of individuals [19]. The transfer of skills and knowledge, however, is a complex area of learning theory that is often assumed and lacks empirical analysis [20]. Stephenson and Yorke argued improving skills, lifelong learning, and welfare-to-work within the setting of the institution can develop the individual's capability [21]. Previous studies indicated how life-skills can be developed in a range of higher education subject areas and noted the change that can be made to the curriculum to facilitate this sort of learning [22]. Previous studies indicated that civic participation leads to transferable capabilities. Facer and Enright suggested the reason that we should promote engaged learning is often answered by reference to the broader civic mission of the university [23]. This idea has played a significant role in the expansion of transferable capabilities; however, the nature of workplace learning is both different from and similar to that found in higher education. Life-long learning in the workplace can be described at different levels, ranging from the individual to the network and region.

Facilitating transfer is critical for preparing students for the effective transition to the workplace. Jackson et al. indicated that work-integrated learning can provide an opportunity for tertiary education students to practice transfer across classroom and work settings [20]. Their findings highlighted the important role of paid work and volunteering and emphasized the importance of educators taking a holistic approach to developing students' transfer ability. $\mathrm{Ng}$ and Harrison reflected on the experience of redesigning a course for online delivery in response to the COVID-19 pandemic while preserving its focus on transferable skills [24]. They provided lessons for developing transferable skills when pivoting to digital learning under extreme conditions.

\subsection{Studies on Civic Engagement and Transferability}

From reviewing previous studies, we found that most of the literature on civic engagement and transferable capabilities came from the United States. For example, Putnam addressed the collapse and revival of the American community and how it played a critical role in increased calls for civic engagement in the undergraduate curriculum [25]. Since then, the American Association of Colleges and Universities (AAC\&U) delivered a definitive call for "personal and social responsibility," "civic knowledge and engagement," and "community-based learning," among other related outcomes and practices [26]. Many others, including academics, led the charge or echoed the appeals for increased civic engagement in the college experience [8,27-31]. Furthermore, the AAC\&U [32], the American Democracy Project [33], the National Conference on Citizenship [34], as well as individual scholars [35,36] identified key practices for engaging students effectively and productively in communities. Lately, studies have addressed this issue from different viewpoints. For 
instance, Richard, et al. suggested that the Adult Civic Engagement model can be used to examine service-learning in higher education [37]. Law indicated that higher education institutions realized they could provide undergraduate students with opportunities through service-learning and community service programs [38]. Walker promoted the case for such an approach in higher education practice, policy, and evaluation [39]. Some studies concerned the means of assessing civic engagement and related capabilities. For example, Brammer and Morton demonstrated that students identified five factors: research, collaboration, effort, passion, and responsibility [40]. Berger indicated that civic engagement, as it is currently used, includes political, social, and moral components, or all public and private goods [11]. This concept shows how education is fundamental to resolving conflicts that involve bias and prejudice, thereby contributing to the well-being of the community. Behind the participation, student affairs professionals, administrators, and faculty defined how students participate to shape civic education experiences on their campus and help students learn how to find and use their voices [41]. This argument seemed to suggest that capabilities might come before civic engagement. In research practice, Mezirow argued that transformative learning challenges students to assess their value system and worldview and to be potentially changed by the experience [42,43]. Moreover, civic engagement is embedded in the history of minority student groups on campuses with their influence on increased access and capacity to inform themselves or others about an issue [44].

In Asia, there are various studies focused on civic engagement, such as that of Seo, et al. based on the community from the perspective of lifelong education. They indicated that education played an important role in establishing a disaster management system by creating a safety culture in the community and by engaging its members [45]. Civic engagement factors have been defined as social trust, volunteer activities, and citizen participation. The participation has extended to town-level civic engagement on a specific eco-mileage program in Korea [46]. This study indicated that civic engagement can play a crucial role to achieve sustainable development goals. Previous studies examined the relationship between the participation of recipient governments and beneficiaries. For example, it has been found that the higher involvement of the beneficiaries leads to better results in the assessment. Their study argued for the inverse relationship between the participation of the recipient governments and the outcome of the assessment [47]. Moreover, with in-depth individual interviews in higher education, Liu and Shen identified four different types of civic activities, including associational membership with the Chinese Communist Party as well as self-organized town-fellowship associations, volunteering, and digital activism, which are analyzed in relation to bridging, bonding, and/or obligatory relationships between the dominant modalities of trust and the typical form of civic participation in Chinese universities [48]. They argued that the hybrid of neoliberal individualism and Confucianism seems to be a perfect match to reconcile the absence of civic traditions and to validate civic consciousness among university youth. We consider that, when students graduate from universities, they might face a society where civic engagement could become a ubiquitous phenomenon. Previous studies have provided strong arguments that civic engagement and transferable capabilities should be set in higher education provisions.

A new large-scale survey was initiated to study civic engagement and its related practices. The NSSE adapted it from a pilot survey developed by the American Association of State Colleges and Universities. The module asks students to assess their conflict resolution skills and examines how often they engage with local or campus issues on a state, national, or global scale [18]. Henceforth, differences in civic engagement across institutions of higher education have emerged [49-53]. For further studies, we may inquire: What kind of function does civic engagement play on campus? Can a student's civic engagement enrich their transferable capabilities? This study assumed that such a latent relationship might exist. 


\section{Methods}

\subsection{Research Framework and Hypotheses}

In this study, we assumed civic engagement would influence college students' transferable capabilities. Figure 1 displays our research framework to be tested in an SEM model. Civic engagement based on a factor analysis might contain various dimensions. Nine indicators representing transferable capabilities will be estimated in the model. They are (1) oral presentation (TC1), (2) critical thinking (TC2), (3) data analysis (TC3), (4) jobrelated skills (TC4), (5) co-operation (TC5), (6) personal values (TC6), (7) realizing (TC7), (8) problem-solving (TC8), and (9) active citizenship (TC9).

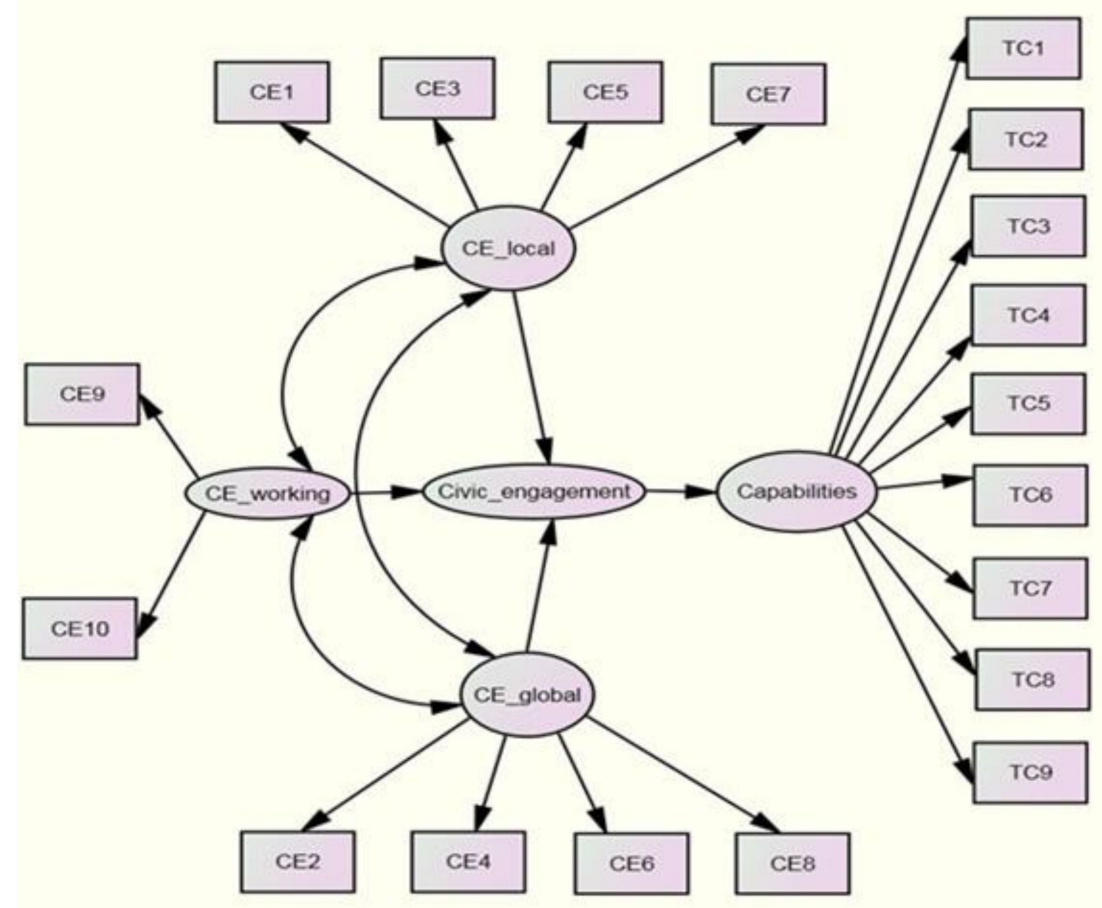

Figure 1. A framework of research.

We developed seven hypotheses regarding students' perceptions of civic engagement and transferable capabilities. The null hypotheses for testing were as follows:

Hypothesis 1 (H1). There is no relationship between civic engagement and transferable capabilities;

Hypothesis 2 (H2). There is no relationship between civic engagement and students engaged in local activities (CE_local);

Hypothesis 3 (H3). There is no relationship between civic engagement and students engaged in global activities (CE_global);

Hypothesis 4 (H4). There is no relationship between civic engagement and students engaged in workable activities (CE_working);

Hypothesis 5 (H5). Students engaged in local activities (CE_local) will not acquire transferable capabilities through civic engagement;

Hypothesis 6 (H6). Students engaged in global activities (CE_global) will not acquire transferable capabilities through civic engagement; 
Hypothesis 7 (H7). Students engaged in workable activities (CE_working) will not acquire transferable capabilities through civic engagement.

\subsection{Instrument}

The questionnaire consisted of demographic variables (gender, college, and family income), time usage (academic activities, extra-curricular activities, leisure, and service activities), learning experiences in one's major, academic performance, civic engagement, and transferable capabilities. The civic engagement indicators were extracted from the NSSE (National Survey of Student Engagement), which provides instruments for educators with an estimate of how undergraduates spend their time and what they gain from attending college [54]. We assumed such an engagement might enhance a student's transferable capabilities. The indicators are listed as follows:

a. Informed yourself about local or campus issues (CE1);

b. Informed yourself about state, national, or global issues (CE2);

c. Discussed local or campus issues with others (CE3);

d. Discussed state, national, or global issues with others (CE4);

e. Raised awareness about local or campus issues (CE5);

f. Raised awareness about state, national, or global issues (CE6);

g. Asked others to address local or campus issues (CE7);

h. Asked others to address state, national, or global issues (CE8);

i. Organized others to work on local or campus issues (CE9);

j. Organized others to work on state, national, or global issues (CE10).

The scale of civic engagement was presented using a 5-point Likert scale, ranging from 1 (never) to 5 (always). Transferable capabilities were presented using a 5-point Likert scale, ranging from 1 (strongly disagree) to 5 (strongly agree). The reliability analysis revealed the Cronbach's alpha to be 0.906 in civic engagement and 0.874 in transferable capabilities.

\subsection{Samples}

The samples were selected from college students and set with a 95\% confident level and possible error control under 0.03 . According to the sampling formula proposed by Dillman [55], the fittest samples for this study can be estimated as follows:

$\mathrm{n}=\mathrm{Z}^{2} / 4^{*} \alpha^{2}=1067$

$\alpha=0.03$ (max acceptable error in sampling)

$\mathrm{Z}=1.96$ (at $\alpha=0.05$ significant level)

The suggested samples in this study were 1067. During the pandemic, the university system in Taiwan was partially locked down. Most campuses were opened conditionally, or, sometimes, courses were offered by the online system (MS Teams). In this study, we expected an $80 \%$ return rate of 1333 copies of the questionnaire. Finally, this study successfully sampled students from public and private universities in Taiwan based on voluntary participation. After deleting incomplete questionnaires, we received 1036 valid responses. The distributions of the samples were $44.5 \%$ male and $55.5 \%$ female. A total of $20.5 \%$ were freshmen, $29.8 \%$ were sophomores, $33.1 \%$ were juniors, and $14 \%$ were seniors. Most were taking STEM and business programs. The sample distribution with basic demographic information is displayed in Table 1. 
Table 1. The distribution of the participating students.

\begin{tabular}{|c|c|c|c|c|}
\hline \multicolumn{2}{|c|}{ Classified } & Frequency & Percent & Valid Percent \\
\hline \multirow{3}{*}{ Gender } & Male & 461 & 44.5 & 44.5 \\
\hline & Female & 575 & 55.5 & 55.5 \\
\hline & Total & 1036 & 100.0 & 100.0 \\
\hline \multirow{7}{*}{ Grade } & Freshman & 212 & 20.5 & 20.5 \\
\hline & Sophomore & 309 & 29.8 & 29.8 \\
\hline & Junior & 343 & 33.1 & 33.1 \\
\hline & Senior & 145 & 14.0 & 14.0 \\
\hline & Extended & 27 & 2.6 & 2.6 \\
\hline & Total & 1036 & 100 & 100 \\
\hline & Humanities & 227 & 21.9 & 22.4 \\
\hline \multirow{6}{*}{ Majors } & STEM & 218 & 21.0 & 21.5 \\
\hline & Business & 226 & 21.8 & 22.3 \\
\hline & Education & 91 & 8.8 & 9.0 \\
\hline & Social Science & 63 & 6.1 & 6.2 \\
\hline & Medicine \& Bio. & 104 & 10.0 & 10.2 \\
\hline & Others & 86 & 8.3 & 8.5 \\
\hline \multirow{3}{*}{ Missing } & Total & 1015 & 98.0 & 100.0 \\
\hline & System & 21 & 2.0 & \\
\hline & & 1036 & 100.0 & \\
\hline
\end{tabular}

\subsection{Statistical Analysis}

We used IBM SPSS software (Statistical Product and Service Solutions) and AMOS (Analysis of Moment Structure) to analyze the data. The level of significant difference was set at $\alpha=0.05$. First, the reliability and validity of the instrument was verified. We carried out factor analysis to estimate the internal constructs of the instrument. Concerning the factor analysis, we set the criteria for the candidate indicators, and factor loadings of less than 0.50 were omitted $[56,57]$. Second, both the Student's $t$-test and ANOVA were used to compare the group differences of civic engagement according to gender and major. In this study, the Shapiro-Wilk statistic was used to determine the samples drawn from the general population. The Levene statistic was used to check the homogeneity of variance in the target groups. An accepted null hypothesis implied that the different samples were drawn from populations having equal variance [58]. If the null hypothesis of homogeneity of variance was accepted $(p>0.05)$, we conducted an ANOVA with the function "equal variance is assumed" in SPSS. The multiple comparison tests were conducted by Turkey's honestly significant difference (Turkey's HSD). If the null hypothesis of homogeneity of variance was rejected $(p<0.05)$, we conducted an ANOVA with the function "equal variance is not assumed" in SPSS. The multiple comparison tests were conducted by Dunnett's T3. Third, the regression model was used to determine the factors of time usage, learning experiences, and academic achievement that might impact civic engagement. Finally, AMOS 26 was used to conduct SEM analysis. We assessed the structural relationships among various civic engagement and transferable capabilities. The overall model fit in SEM was assessed using common goodness-of-fit indices, including Chi-square minimum $(\mathrm{CMIN})$, the ratio of Chi-square to degrees of freedom $\left(\chi^{2} / \mathrm{df}<3.0\right)$, number of distinct parameters (NPAR), goodness-of-fit index (GFI > 0.90), adjusted goodness-of-fit index (AGFI > 0.90), parsimonious goodness-of-fit index (PGFI > 0.50), and root-mean-square residual (RMR tends to be relatively smaller) [59,60].

\section{Results}

\subsection{Verifying the Dimensions of Civic Engagement}

The factor analysis indicated civic engagement with three factors, namely: engaged in local or campus (CE_local), engaged in national or global issues (CE_global), and engaged in workable activities (CE_working). The Kaiser-Meyer-Olkin measure of sampling adequacy result was 0.887 , and Bartlett's test of sphericity showed that the Chi-square was 
approximately $9078.099(p=0.000)$. Both indices suggest that the targeted 1036 sample was fitted to conduct factor analysis. Table 2 shows the results of the factor analysis based on the principal component analysis. The three factors can explain $80.49 \%$ of the variance. It is a good measure with good factorial structures.

Table 2. Component matrix of civic engagement with principal component analysis.

\begin{tabular}{|c|c|c|c|c|}
\hline Indicators & Definitions & Factor 1 & Factor 2 & Factor 3 \\
\hline CE2 & $\begin{array}{l}\text { Informed yourself about state, } \\
\text { national, or global issues; }\end{array}$ & 0.850 & & \\
\hline CE4 & $\begin{array}{l}\text { Discussed state, national, or } \\
\text { global issues with others; }\end{array}$ & 0.821 & & \\
\hline CE6 & $\begin{array}{l}\text { Raised awareness about state, } \\
\text { national, or global issue: }\end{array}$ & 0.786 & & \\
\hline CE8 & $\begin{array}{c}\text { Asked others to address state, } \\
\text { national, or global issues; }\end{array}$ & 0.671 & & \\
\hline CE1 & $\begin{array}{l}\text { Informed yourself about local } \\
\text { or campus issues; }\end{array}$ & & 0.823 & \\
\hline CE3 & $\begin{array}{l}\text { Discussed local or campus } \\
\text { issues with other; }\end{array}$ & & 0.806 & \\
\hline CE5 & $\begin{array}{c}\text { Raised awareness about local or } \\
\text { campus issues; }\end{array}$ & & 0.716 & \\
\hline CE7 & $\begin{array}{c}\text { Asked others to address local or } \\
\text { campus issues; }\end{array}$ & & 0.618 & \\
\hline CE10 & $\begin{array}{l}\text { Organized others to work on } \\
\text { state, national, or global issues. }\end{array}$ & & & 0.886 \\
\hline CE9 & $\begin{array}{l}\text { Organized others to work on } \\
\text { local or campus issues; }\end{array}$ & & & 0.875 \\
\hline
\end{tabular}

Note. Extraction Method: Principal Component Analysis; Rotation Method: Varimax with Kaiser Normalization.

\subsection{Comparing Group Differences of Civic Engagement}

The results revealed the mean of the students' civic engagement to be 3.116, at a middling level (on 5-point Likert scale); CE_local was 3.121; CE_global was 3.344; and CE_working was 2.650. The CE_working value is below the average. Comparing the gender differences in civic engagement, the Levene $F$ value was 4.759 , with the mean for testing homogeneity of variance being $p=0.029$. It implied that equal variances were not assumed. The results revealed no significant difference between males and females $(t=1.041, p=0.298)$. Determining the differences according to students' majors, the results revealed the Levene $\mathrm{F}$ values of those groups to be 3.18 based on the mean $(p=0.928)$. The results indicated the group sample data fit the homogeneity of variance. The ANOVA test revealed that $\mathrm{F}=2.864$ and $p=0.009$. In this case, we conducted Turkey's HSD for a group difference comparison. The results showed that students in social science programs (I) showed stronger civic engagement than those in a business major $(\mathrm{J})(\mathrm{I}-\mathrm{J}=3.382, p=0.027)$. Students majoring in the humanities (I) performed better than those in business (J). The mean difference $(\mathrm{I}-\mathrm{J}=2.066, p=0.053)$ was marginal. The other programs did not show any difference in student civic engagement (Table 3 ). In this study, we also found that there is no grade difference $(\mathrm{F}(4,1031)=1.782, p=0.130$, with equal variances assumed $)$. 
Table 3. Multiple comparisons of civic engagement with students' majors.

\begin{tabular}{ccccc}
\hline $\begin{array}{c}\text { (I) Majors or } \\
\text { Colleges }\end{array}$ & $\begin{array}{c}\text { (J) Majors or } \\
\text { Colleges }\end{array}$ & $\begin{array}{c}\text { Mean } \\
\text { Difference (I-J) }\end{array}$ & Std. Error & Sig. $\boldsymbol{p}$ \\
\hline \multirow{4}{*}{ Humanities } & STEM & 1.417 & 0.712 & 0.421 \\
& Business & 2.066 & 0.705 & 0.053 \\
& Education & 0.270 & 0.931 & 1.000 \\
& Social Science & -1.316 & 1.069 & 0.882 \\
& Medicine \& Bio. & 1.441 & 0.888 & 0.668 \\
& Others & 0.192 & 0.950 & 1.000 \\
STEM & Business & 0.650 & 0.712 & 0.971 \\
& Education & -1.146 & 0.936 & 0.885 \\
& Social Science & -2.732 & 1.073 & 0.144 \\
& Medicine \& Bio. & 0.0240 & 0.894 & 1.000 \\
Business & Others & -1.225 & 0.955 & 0.860 \\
& Education & -1.796 & 0.932 & 0.462 \\
& Social Science & $-3.382 *$ & 1.069 & 0.027 \\
& Medicine \& Bio. & -0.626 & 0.889 & 0.992 \\
Education & Others & -1.874 & 0.951 & 0.434 \\
& Social Science & -1.58608 & 1.230 & 0.857 \\
& Medicine \& Bio. & 1.17033 & 1.077 & 0.932 \\
Social Science & Others & -0.07833 & 1.128 & 1.000 \\
Medicine and Bio & Medicine \& Bio. & 2.75641 & 1.198 & 0.244 \\
& Others & 1.50775 & 1.244 & 0.890 \\
& Others & -1.24866 & 1.094 & 0.915 \\
\hline
\end{tabular}

Note. Method: Turkey's HSD; ${ }^{*} p<0.05 ; 1$ = Humanities; 2 = STEM; 3 = Business; 4 = Education; 5 = Social science $6=$ Medicine and Bio.; 7 = Others.

\subsection{Factors Affecting Civic Engagement}

Regression analysis was used to verify the impact of independent variables on civic engagement. These included the time spent doing coursework, engaging in extra-curricular activities, participating in social service, caring for family, commuting, leisure/social networking, learning experiences, and academic performance in the regression model. The results revealed that learning experiences, participating in social service, engaging in extra-curricular activities, and leisure/social networking showed a good relation to civic engagement $\left(R^{2}=0.125\right)$. In this model, the value of Durbin-Watson was 1.879 , implying the residual tends to zero.

\subsection{Relationships between Civic Engagement and Transferable Capabilities}

We found the CMIN was 711.221 in the default model. In this study, the $\chi^{2} / \mathrm{df}$ index value was $5.08\left(\chi^{2}=711.221 ; \mathrm{df}=140\right)$. In this case, we were not sure that the model was a good fit. A previous study argued that it is often easier for $\chi^{2}$ to reach statistical significance with large samples [61,62]. In this study, we assumed our measurement model (the default model in AMOS) to be "not independent" from the data of the observations. After recalculating with the scaled non-centrality parameter (SNCP) for large samples, we found that SNCP $=\left(\chi^{2}-\mathrm{df}\right) / \mathrm{n}=(771.221-140) / 1036=0.551$, indicating a good fit $(0.551<3.00)$. The SEM revealed the NPAR (the number of parameters) to be 50 , implying that the model was defined as complex. The results revealed that the model-fit indices exceeded the acceptance levels (GFI $=0.982>0.90$, AGFI $=0.975>0.90$, PGFI $=0.735>$ $0.50, \mathrm{RMR}=0.058$ ). The results of the SEM demonstrated the recommended values for the model fit. Table 4 and Figure 2 display the estimated and standardized coefficients in the paths and $p$-values. We consider the effect size of the coefficient according to the $r$-value standards proposed by Cohen [63], where $r=0.1$ is a small effect, $r=0.3$ is a medium effect, and $r=0.5$ is a large effect. The results displayed most of the relationships except $\mathrm{H} 4$ and H7. We found the significant path coefficient of CE_Local to Civic_engagement is 0.45 and the path coefficient of CE_Global to Civic_engagement is 0.22; both tend to be low. The path coefficient of Civic_engagement to Capabilities is 0.71 ; it looks better in this model. The results of the null hypothesis tests are listed as follows. 
Table 4. The estimated and standardized coefficients and significance of $p$-values.

\begin{tabular}{|c|c|c|c|c|c|}
\hline Hypotheses & & & Estimated & Standardized & $p$ \\
\hline H1: Transferable capabilities & $\leftarrow$ & Civic engagement & 0.479 & 0.705 & * \\
\hline $\mathrm{H} 2$ : Civic engagement & $\leftarrow$ & Engaged in local activities (CE_local) & 0.532 & 0.446 & * \\
\hline H3: Civic engagement & $\leftarrow$ & Engaged in global activities (CE_global) & 0.271 & 0.225 & * \\
\hline H4: Civic engagement & $\leftarrow$ & Engaged in working activities (CE_working) & 0.088 & 0.067 & - \\
\hline $\begin{array}{c}\text { H5: Capabilities/Civic } \\
\text { engagement }\end{array}$ & $\leftarrow$ & Engaged in local activities (CE_local) & $\begin{array}{c}0.255 / \\
0.531\end{array}$ & $\begin{array}{c}0.446 / \\
0.315\end{array}$ & $*$ \\
\hline $\begin{array}{l}\text { H6: Capabilities/Civic } \\
\text { engagement }\end{array}$ & $\leftarrow$ & Engaged in local activities (CE_global) & $\begin{array}{c}0.130 / \\
0.271\end{array}$ & $\begin{array}{c}0.225 / \\
0.158\end{array}$ & $*$ \\
\hline $\begin{array}{l}\text { H7: Capabilities/Civic } \\
\text { engagement }\end{array}$ & $\leftarrow$ & Engaged in local activities (CE_working) & $\begin{array}{c}0.042 / \\
0.088\end{array}$ & $\begin{array}{l}0.067 / \\
0.047\end{array}$ & - \\
\hline
\end{tabular}

Note. ${ }^{*} p<0.05$

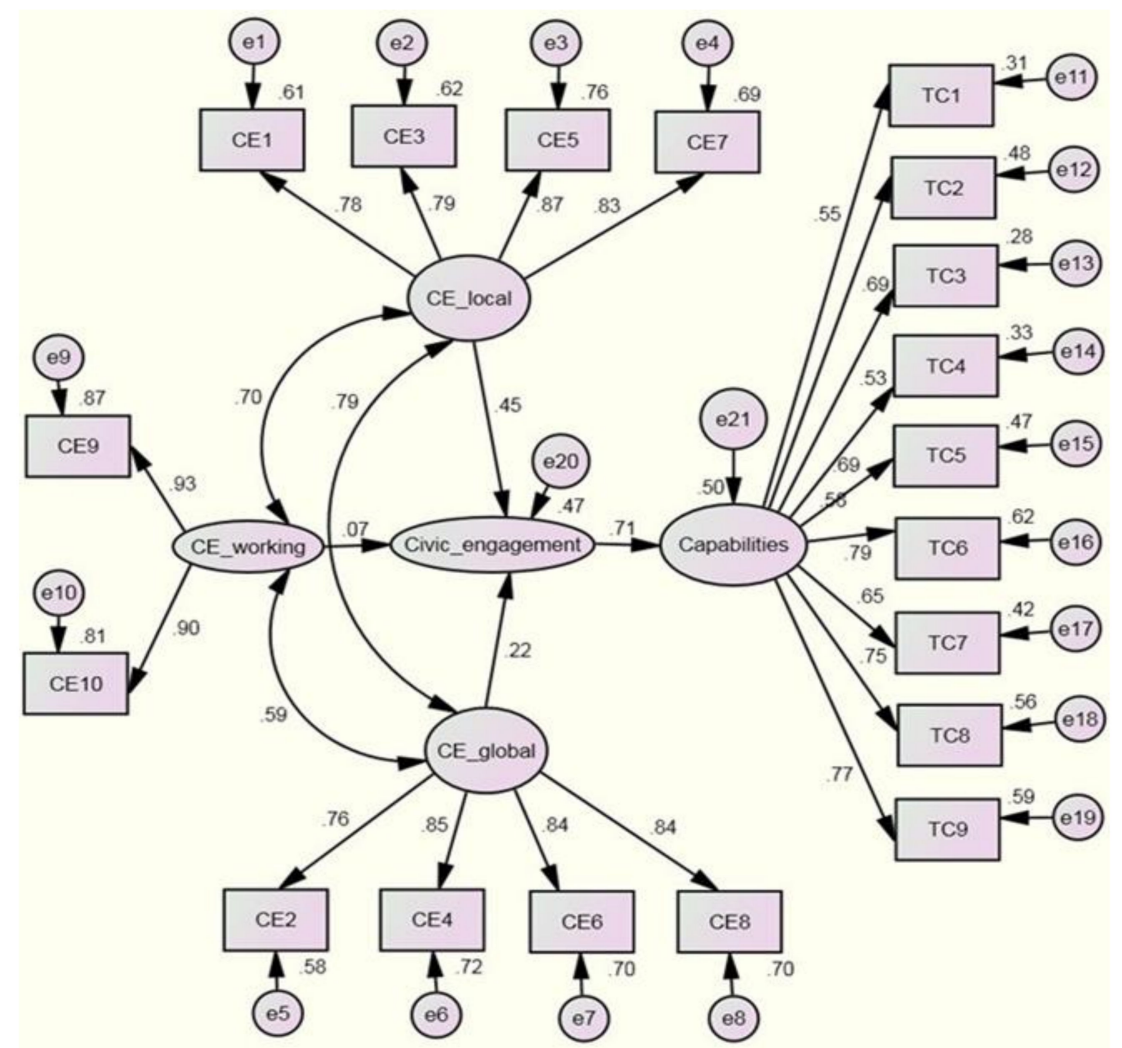

Figure 2. The result of SEM.

Hypothesis 1 (H1). There is no relationship between civic engagement and transferable capabilities (Rejected);

Hypothesis 2 (H2). There is no relationship between students engaged in local activities (CE_local) and civic engagement (Rejected);

Hypothesis 3 (H3). There is no relationship between students engaged in global activities (CE_global) and civic engagement (Rejected);

Hypothesis 4 (H4). There is no relationship between students engaged in workable activities (CE_working) and civic engagement (Accepted);

Hypothesis 5 (H5). Students engaged in local activities (CE_local) will not acquire transferable capabilities through civic engagement (Rejected); 
Hypothesis 6 (H6). Students engaged in global activities (CE_global) will not acquire transferable capabilities through civic engagement (Rejected);

Hypothesis 7 (H7). Students engaged in workable activities (CE_working) will not acquire transferable capabilities through civic engagement (Accepted).

\subsection{Validation of Reflective Constructs}

Construct development and the use of structural equation modeling have become important processes of research. The direction of the relationship between the measures and latent constructs might cause measurement model misspecification issues. The two types of latent construct measurement models are reflective and formative. Reflective measures are caused by the latent construct, whereas formative measures cause the latent construct. In this study, civic engagement can be viewed as formative measures, while the capabilities will be treated as reflective measures. In this model, civic engagement also counts as a reflective measure when considering the three components of the observations. In this study, we verify the construct based on the following criteria: the indicators should possess internal consistency, the acceptable variance is explained, and the removal of an item does not change the essential nature of the underlying construct. Typically, high indicator correlations may not exist with formative constructs. High correlations among formative indicators could indicate that the scale items are measuring essentially the same concept. This could lead to a multi-collinearity problem and the need to eliminate one or more indicators. In this study, the mean of inter-item correlations was 0.485 . The information for Cronbach's alpha if item deleted is displayed in Table 5. The validation of the reflective constructs was based on the composite reliability and variance explained by the measures. Table 6 displays the details. The validation of the reflective construct provides strong evidence for the relationship between civic engagement and capabilities. The weak linkage of the SEM model may reflect the particular participants in a special moment.

Table 5. Item-total statistics for civic engagement measures.

\begin{tabular}{cccccc}
\hline Indicators & $\begin{array}{c}\text { Scale Mean } \\
\text { If Item } \\
\text { Deleted }\end{array}$ & $\begin{array}{c}\text { Scale } \\
\text { Variance If } \\
\text { Item Deleted }\end{array}$ & $\begin{array}{c}\text { Corrected } \\
\text { Item-Total } \\
\text { Correlation }\end{array}$ & $\begin{array}{c}\text { Squared } \\
\text { Multiple } \\
\text { Correlation }\end{array}$ & $\begin{array}{c}\text { Cronbach's } \\
\text { Alpha If } \\
\text { Item Deleted }\end{array}$ \\
\hline CE1 & 28.58 & 39.908 & 0.712 & 0.609 & 0.894 \\
CE2 & 28.21 & 40.931 & 0.636 & 0.622 & 0.898 \\
CE3 & 28.45 & 39.919 & 0.715 & 0.627 & 0.894 \\
CE4 & 28.37 & 39.976 & 0.714 & 0.680 & 0.894 \\
CE5 & 28.67 & 38.697 & 0.792 & 0.708 & 0.888 \\
CE6 & 28.43 & 39.604 & 0.722 & 0.668 & 0.893 \\
CE7 & 28.77 & 39.214 & 0.746 & 0.633 & 0.891 \\
FE8 & 27.98 & 45.604 & 0.269 & 0.089 & 0.917 \\
CE9 & 29.10 & 39.354 & 0.668 & 0.777 & 0.897 \\
CE10 & 29.08 & 39.303 & 0.653 & 0.742 & 0.898 \\
\hline
\end{tabular}

Table 6. Validation of reflective constructs.

\begin{tabular}{cccc}
\hline Reflexive Construct & $\begin{array}{c}\text { Composite Reliability } \\
\text { (Cronbach's Alpha) }\end{array}$ & $\begin{array}{c}\text { Variance } \\
\text { Explained }\end{array}$ & AVE \\
\hline Criteria & $>0.7$ & $>0.50$ & $>0.50$ \\
Measures: & & & \\
Civic engagement & 0.906 & 0.80 & $>0.50$ \\
CE_local & 0.890 & 0.61 & $>0.50$ \\
CE_global & 0.893 & 0.12 & $<0.50$ \\
CE_working & 0.912 & 0.08 & $>0.50$ \\
Capabilities & 0.874 & 0.51 & $>0.50$ \\
\hline
\end{tabular}




\section{Discussion}

Previous studies provided various perspectives and practices for tackling civic engagement issues in diverse settings $[17,31,37]$. Considering the impact of the COVID-19 pandemic, this study intended to investigate students' civic engagement and its linkage in a specific higher education system. Even though the NSSE modules provided various functions for realizing the progress of students' campus life [54], they could not detect the linkage among major factors. This study proposed a new framework to test the structural relationship between civic engagement and transferable capabilities. It is important to appreciate the new situation and how civic engagement can be enhanced to prompt students to acquire transferable capabilities. Based on the findings, activities on campus have obviously been impeded by the pandemic. At the average level, it is similar to local and global civic engagement in this study. Facing an uncertain environment, the dimension of working on related activities (CE_working dimension) perceived by students was relatively low. We found that the designed instrument with factorial dimensions could be used to explore civic engagement more accurately, and this survey could be extended to different colleges. For example, it found that students in business programs showed low civic engagement, while students in the social science programs showed high civic engagement. The factorial structure provides a precise measurement to test students' progress of civic engagement in various programs.

COVID-19 caused widespread university system lockdowns, and the findings suggested that related factors impacted civic engagement. Since the $\mathrm{R}^{2}$ in the regression model was slim, those factors were transformed temporarily, which is different from the findings of previous studies $[14,15,40]$. In addition, this study found a causal relationship between civic engagement and transferable capabilities in the structural equation modeling. Previous studies argued that students participating in learning activities for competencies on campus will continue community or global engagement after they graduate $[23,37,38,41]$. This study focused on students' campus life and found that civic engagement was connected with their capabilities. In this case, local and global engagement were the major contributors. Moreover, the findings may suggest that grouping people and work with civic engagement activities is a weak link, but the results might be affected by the COVID-19 pandemic. In view of the lockdowns and the fact that not all citizens had been vaccinated, encouraging students to organize others to work on local or global issues was very tough. The suggests that university management teams need to review the current measures in departments to ameliorate ineffective student practices.

\section{Conclusions}

Civic engagement has become a crucial component of student learning. This study provided a practical example to detect civic engagement in higher education. The findings suggested that enhancing civic engagement must consider students' majors, learning experiences in departments, and time spent on related activities: social service, extracurricular activities, and leisure/social networking. Exploring various dimensions of civic engagement can provide useful information for enhancing the ongoing practices of higher education. Based on these findings, we found students' civic engagement needs enhancement, especially for those studying business.

Hopefully, the pandemic might only exist for a short time more, but we suggest improving provisions for civic engagement in courses of study along three dimensions: engagement in campus or local issues, national or global issues, and work issues. This study extended the causal relationship in SEM and provided an example of a testing model to evaluate student civic engagement and transferable capabilities. This instrument can be used to evaluate progress on campus even after the pandemic. Since the sustainable development has become a long-term goal in higher education, we suggest the linkage of civic engagement and transferable capabilities can provide a meaningful construct for enhancing students' participation in social activities for the public good. 
Finally, based on these findings, we suggest enhancing students' civic engagement through campus activities. During the pandemic, departments or campuses initiated online networks or related social media to encourage students to participate in group discussions. We found the actual implementation became unworkable during this period. For departments, we suggest open, virtual, or simulated situations to widen student participation through virtual meeting tools, such as MS Teams, Cisco WebEx, Google Meet, or TeamViewer. Moreover, the proposed research framework can be broadened to explore similar issues in higher education.

Author Contributions: Conceptualization, D.-F.C.; methodology, D.-F.C.; software, D.-F.C.; validation, D.-F.C., T.-N.C. and C.-C.C.; formal analysis, D.-F.C.; investigation, D.-F.C., T.-N.C. and C.-C.C.; writing—original draft preparation, D.-F.C., T.-N.C. and C.-C.C.; writing—review and editing, D.-F.C.; All authors have read and agreed to the published version of the manuscript.

Funding: This research received no external funding.

Institutional Review Board Statement: Not applicable.

Informed Consent Statement: Not applicable.

Data Availability Statement: Most of data transformation is contained within the article. Data available on request due to restrictions. The data presented in this study are available on request from the corresponding author.

Acknowledgments: The authors wish to express their gratitude to the international students participated in this study. The author wish to thank the three anonymous reviewers for their valuable comments.

Conflicts of Interest: The authors declare no conflict of interest.

\section{References}

1. Batubara, B.M. The problems of the world of education in the middle of the COVID-19 Pandemic. Bp. Int. Res. Crit. Inst. (BIRCI-J.) Humanit. Soc. Sci. 2021, 4, 450-457. Available online: http://bircu-journal.com/index.php/birci/article/View/1626 (accessed on 2 July 2021).

2. Doucet, A.; Netolicky, D.; Timmers, K.; Tuscano, F.J. Thinking about Pedagogy in an Unfolding Pandemic. Work of Education International and UNESCO. 2020. Available online: https://issuu.com/educationinternational/Docs/2020_research_covid-19 _eng (accessed on 2 July 2021).

3. Mok, K.H.; Xiong, W.; Ke, G.; Cheung, J.O.W. Impact of COVID-19 Pandemic on international higher education and student mobility: Student perspectives from mainland China and Hong Kong. Int. J. Educ. Res. 2021, 105, 101718. [CrossRef]

4. Wu, S.-J.; Chang, D.-F.; Sun, F.-R. Exploring college student's perspectives on global mobility during the COVID-19 pandemic recovery. Educ. Sci. 2020, 10, 218. [CrossRef]

5. Abdelsalam, M.M.; Ebitisam, K.E.; Shadi, A.; Hasan, R.; Hadeel, A. The COVID-19 pandemic and E-learning: Challenges and opportunities from the perspective of students and instructors. J. Comput. High. Educ. 2021, 3, 1-18.

6. Fakari, F.R.; Hajian, S. COVID-19-opportunity for online education: Do not forget the ethical considerations in teaching learners. J. Educ. Health Promot. 2021, 10, 162.

7. Mukhtar, K.; Javed, K.; Arooj, M.; Sethi, A. Advantages, limitations and recommendations for online learning during COVID-19 pandemic era. Pak. J. Med Sci. 2020, 36, S27-S31. [CrossRef]

8. Jacoby, B. Civic Engagement in Higher Education: Concepts and Practices; Jossey-Bass: San Francisco, CA, USA, 2009.

9. Mtawa, N.N. Human Development and Community Engagement through Service-Learning: The Capability Approach and Public Goods in Education; Palgrave Macmillan: Cham, Switzerland, 2019.

10. McIlrath, L. Campus Cartography-A Qualitative Inquiry into Civic Engagement and Service Learning within Three European Universities. Ph.D. Thesis, Queen's University Belfast, Belfast, Northern Ireland, 2018.

11. Berger, B. Political theory, political science and the end of civic engagement. Perspect. Politics 2009, 7, 335-350. [CrossRef]

12. Dostilio, L.D. The Community Engagement Professional in Higher Education: A Competency Model for an Emerging Field; Stylus Publishing: Sterling, VA, USA, 2017.

13. Saltmarsh, J.A. Collaborative turn: Trends and directions in community engagement. In Learning Through Community Engagement; Sachs, J., Clark, L., Eds.; Springer: Singapore, 2017; pp. 3-15.

14. Broom, C. (Ed.) Youth Civic Engagement in a Globalized World: Citizenship Education in Comparative Perspective; Palgrave Macmillan: New York, NY, USA, 2016.

15. Campbell, D.E. Civic engagement and education: An empirical test of the sorting model. Am. J. Political Sci. 2009, 53, 771-786. [CrossRef] 
16. Brannelly, L.; Lewis, L.; Ndaruhutse, S. Higher Education and the Formation of Developmental Elites: A Literature Review and Pre-Liminary Data Analysis; Development Leadership Program, CfBT Education Trust: Reading, UK, 2011.

17. Schweisfurth, M.; Davies, L.; Symaco, L.P.; Valiente, O. Higher education, bridging capital, and developmental leadership in the Philippines: Learning to be a crossover reformer. Int. J. Educ. Dev. 2018, 59, 1-8. [CrossRef]

18. NSSE. 2016 Topical Module: Civic Engagement. 2017. Available online: http://nsse.indiana.edu/2016_institutional_report/pdf/ Modules/NSSE16\%20Module\%20Summary-Civic\%20Engagement.Pdf (accessed on 10 September 2020).

19. Nägele, C.; Stalder, B.E. Competence and the need for transferable skills. In Technical and Vocational Education and Training: Issues, Concerns and Prospects; Gabler: Wiesbaden, Germany, 2017; pp. 739-753. [CrossRef]

20. Jackson, D.; Fleming, J.; Rowe, A. Enabling the transfer of skills and knowledge across classroom and work contexts. Vocat. Learn. 2019, 12, 459-478. [CrossRef]

21. Stephenson, J.; Yorke, M. (Eds.) Capability and Quality in Higher Education; Routledge: London, UK, 2013. [CrossRef]

22. Assiter, A. Transferable Skills in Higher Education; Routledge: London, UK, 2017. [CrossRef]

23. Facer, K.; Enright, B. A question of purpose: Engaged learning and the research mission of the university. In Learning Through Community Engagement; Sachs, J., Clark, L., Eds.; Springer: Singapore, 2017; pp. 53-64.

24. Ng, F.; Harrison, J. Preserving transferable skills in the accounting curriculum during the COVID-19 pandemic. Account. Res. J. 2021, 34, 290-303. [CrossRef]

25. Etzioni, A.; Putnam, R.D. Is bowling together sociologically lite? Bowling alone: The collapse and revival of American Community. Contemp. Soc. A J. Rev. 2001, 30, 223. [CrossRef]

26. The National Task Force on Civic Learning and Democratic Engagement. A Crucible Moment: College Learning and Democracy's Future; Association of American Colleges and Universities: Washington, DC, USA, 2012.

27. Boyte, H.; Hollander, E. Wingspread Declaration on Renewing the Civic Mission of the American Research University; University of Michigan Center for Community Service Learning: Ann Arbor, MC, USA, 1999.

28. Colby, A.; Beaumont, E.; Ehrlich, T.; Corngold, J. Educating for Democracy: Preparing Undergraduates for Responsible Political Engagement; Jossey-Bass: San Francisco, CA, USA, 2007.

29. Colby, A.; Ehrlich, T.; Beaumont, E.; Stephens, J. Educating Citizens: Preparing America's Undergraduates for Lives of Moral and Civic Responsibility; Jossey-Bass: San Francisco, CA, USA, 2003.

30. Ehrlich, T. Introduction. In Civic Responsibility and Higher Education; Colby, A., Ehrlich, T., Beaumont, E., Rosner, J., Stephens, J., Eds.; The American Council on Education and The Oryx Press: Phoenix, AZ, USA, 2000; pp. Xliii-Xxi.

31. Barnhardt, C.L.; Trolian, T.; An, B.; Rossmann, P.D.; Morgan, D.L. Civic learning while earning? The role of student employment in cultivating civic commitments and skills. Rev. High. Educ. 2019, 42,707-737. [CrossRef]

32. Association of American Colleges and Universities. Core Commitments: Educating Students for Personal and Social ResponSibility. 2012. Available online: http:/ / www.aacu.org/core_commitments/index.Cfm (accessed on 25 June 2021).

33. American Democracy Project. Creating Civic Outcomes: Designing Signature Pedagogies Selected Examples; American Association of State Colleges and Universities: Washington, DC, USA, 2012.

34. National Conference on Citizenship. National Conference on Citizenship 2020 Report. 2020. Available online: https:/ / ncoc.org/ National-Conference-on-Citizenship-2020-Report/ (accessed on 20 May 2021).

35. Gottlieb, K.; Robinson, G. Integrating Civic Responsibility into the Curriculum; The American Association of Community Colleges: Washington, DC, USA, 2002.

36. Stokamer, S.T. Pedagogical catalysts of civic competence: The development of a critical epistemological model for communitybased learning. J. High. Educ. Outreach Engagement 2011, 17, 113-121.

37. Doberneck, D.M.; Bargerstock, B.A.; McNall, M.; Egeren, L.V.; Zientek, R. Community engagement competencies for graduate and professional students: Michigan State University's approach to professional development. Mich. J. Commu. Serv. Learning. 2017, 24, 122-142.

38. Law, W.-W. Higher Education in Post-1997 Hong Kong: Politics, academic freedom, and civic engagement. In The Changing Academic Profession in Hong Kong; Gabler: Wiesbaden, Germany, 2017; pp. 39-75. [CrossRef]

39. Walker, M. Advancing student well-being and agency: The outline of a capabilities-friendly approach. S. Afr. J. High. Educ. 2016, 29, 279-296. [CrossRef]

40. Brammer, L.R.; Morton, A. Course-based civic engagement: Understanding student perspectives and outcomes. Int. J. Sch. Teach. Learn. 2014, 8, 8. [CrossRef]

41. Terzi, L. The capability to be educated. In Amartya Sen's Capability Approach and Social Justice in Education; Walker, M., Unterhalter, E., Eds.; Palgrave Macmillan: New York, NY, USA, 2007; pp. 25-43.

42. Mezirow, J. Transformative Dimensions of Adult Learning; Jossey-Bass: San Francisco, CA, USA, 1991.

43. Mezirow, J. Contemporary paradigms of learning. Adult Educ. Q. 1996, 46, 158-172. [CrossRef]

44. Fassett, K.T.; Priddie, C.; BrckaLorenz, A.; Kinzie, J. Activists, non-activists, and allies: Civic engagement and student types at MSIs. Front. Educ. 2018, 3, 103. [CrossRef]

45. Seo, H.; Son, M.; Hong, A. Trends in civic engagement disaster safety education research: Systematic literature review and keyword network analysis. Sustainability 2021, 13, 2505. [CrossRef]

46. Kim, J.; Jung, T.; Kim, Y. Multilevel analysis of civic engagement and effectiveness of energy transition policy in Seoul: The seoul eco-mileage program. Sustainability 2020, 12, 9905. [CrossRef] 
47. Kim, S.; Sohn, H.-S.; Lee, J. Evaluating participation: Empirical analysis of recipient and beneficiary engagement with IFAD international development projects. Sustainability 2020, 12, 5862. [CrossRef]

48. Liu, Y.; Shen, W. Perching birds or scattered streams: A study of how trust affects civic engagement among university students in contemporary China. High. Educ. 2021, 81, 421-436. [CrossRef]

49. Evans, B.J.; Marsicano, C.R.; Lennartz, C.J. Cracks in the bedrock of american democracy: Differences in civic engagement across institutions of higher education. Educ. Res. 2019, 48, 31-44. [CrossRef]

50. McIlrath, L. The Civic University: A legal and policy vacuum? In Learning Through Community Engagement; Sachs, J., Clark, L., Eds.; Springer: Singapore, 2017; pp. 17-29.

51. Mumford, M.D.; Robert, M.; Elliott, S.; Todd, E.M. Leading social innovation and community engagement. In The Cambridge Handbook of Organizational Community Engagement and Outreach; Allen, J.A., Reiter-Palmon, R., Eds.; Cambridge University Press: Cambridge, UK, 2019; pp. 261-280.

52. New England Resource Center for Higher Education. Carnegie Community Engagement Classification Resources. 2015. Available online: https: / / nerche.org/Carnegie-Engagement-Classification/ (accessed on 12 June 2021).

53. Wray-Lake, L.; Metzger, A.; Syvertsen, A.K. Testing multidimensional models of youth civic engagement: Model comparisons, measurement invariance, and age differences. Appl. Dev. Sci. 2016, 21, 266-284. [CrossRef]

54. NSSE. Civic Engagement Topical Module. 2020. Available online: https://nsse.indiana.edu/nsse/survey-instruments/topicalmodules/civic-engagement.Html (accessed on 20 September 2020).

55. Dillman, D.A. Internet and Mail Surveys: The Tailored Design Method; John Wiley: New York, NY, USA, 2000.

56. Bentler, P.M. Comparative fit indexes in structural models. Psychol. Bull. 1990, 107, 238-246. [CrossRef]

57. Walker, S.L.; Fraser, B.J. Development and validation of an instrument for assessing distance education learning environments in higher education: The Distance Education Learning Environments Survey (DELES). Learn. Environ. Res. 2005, 8, 289-308. [CrossRef]

58. Aljandali, A. Multivariate Methods and Forecasting With IBM ${ }^{\circledR}$ SPSS ${ }^{\circledR}$ Statistics; Gabler: Wiesbaden, Germany, 2017. [CrossRef]

59. Wardrop, J.L.; Loehlin, J.C. Latent variable models: An introduction to factor, path, and structural analysis. J. Educ. Stat. 1987, 12, 410. [CrossRef]

60. Schumacker, R.E.; Lomax, R.G. A Beginner's Guide to Structural Equation Modeling; Lawrence Erlbaum Associate: Mahwah, NJ, USA, 2004.

61. Kenny, D.A. Measuring Model Fit. 2020. Available online: http:/ / davidakenny.net/cm/fit.Htm (accessed on 20 July 2021).

62. Yaşlioğlu, M.; Yaşlioğlu, D.T. How and when to use which fit indices? A practical and critical review of the methodology. Istanb. Manag. J. 2020, 88, 1-20. [CrossRef]

63. Cohen, J. Statistical Power Analysis for the Behavioral Sciences, 2nd ed.; Routledge Academic: New York, NY, USA, 1988. 